\title{
Grundtvig och Geijer - Två nordiska giganter
}

\author{
Af Gert Nilsson
}

Lennart Behrendtz \& Björn Skogar (red), Grundtvig, Geijer och deras verkningshistoria. Rapport från ett symposium på Högskolan i Karlstad, 1996. Högskolan i Karlstad, Utvecklingsrapport 97:2, Samhällsvetenskap.

Lundabiskopen Edvard Rodhe gjorde vid ett tillfälle (1942) en antydan till en jämförelse mellan Erik Gustaf Geijer och N.F.S. Grundtvig, dessa två giganter i 1800-talets kultur- och kyrkoliv. Rodhe skriver, träffande, att »Grundtvigs insats blev mera djupgående och påtaglig, liksom hans namn på ett annat sätt gått ut över världen." (Edv. Rodhe: Geijer och Samhället, Lund 1942, s. 507) Så förhåller det sig verkligen. Vad som är orsaken till att den ene alltjämt är aktuell medan den andre är förvisad till en museal kammare är emellertid långt ifrån klarlagt. Det beror inte alltid eller enbart på en enskild person vilket inflytande hennes eller hans tankar kommer att få. Stöd från i sammanhanget mäktiga och inflytelserika personer kan betyda mycket. Paradoxalt nog var det Geijer som fick detta stöd medan Grundtvig fick kämpa ensam, utfrusen från det akademiska etablissemanget. Medan Geijer bekläddes med höga poster och hedersbetygelser, fick Grundtvig nöja sig med den plats hans kyrka tilldelade honom: att vara ålderdomshemspredikant på Vartov. Det hör till Grundtvigs storhet att han accepterade denna uppgift och gjorde något stort av den. Nåja, helt utan hedersbetygelser blev Grundtvig inte: han tilldelades samma rang som Själlands biskop.

Men det kan också vara kulturklimatet som avgör hur en persons tankar skall tas emot, värderas och föras vidare. Kanske är det här vi skall söka svaret på frågan varför Grundtvigs insats blev djupare och mer bestående än Geijers; att den danska kulturen gav en bättre jordmån för Grundtvig än den svenska för Geijer.

En av bokens redaktörer, Björn Skogar, målar i sin inledning upp en träffande bild. När kyrkan i Ransäter - Geijers födelseförsamling - på 1980talet brann ner till grunden, ersattes den av en byggnad som till det yttre var identisk med den nedbrunna 1600-talskyrkan. Invändigt är den däremot förändrad. Som altartavla finns en ikon, alltså en målning med hemort i den österländska kyrkan. En svensk landsbygdskyrka har alltså fått en utformning av koret som saknar varje som helst stöd i den kyrkliga traditionen. Detta, menar Skogar, är ett utslag av dålig teologi och märklig kyrkosyn. I Ransäter finns också en folkhögskola, Geijerskolan, med inriktning på musik. Eftersom Geijer var både diktare och tonsättare skulle man kunnat vänta sig att Geijerskolan hade specialiserat sig på just Geijers musik; Göran B. Nilsson gör en antydan i den riktningen i sitt bidrag. Det har man emellertid inte gjort. I stället har skolan specialiserat sig på afrikansk musik. Med tanke på att Geijer 
var musikalisk allätare borde båda riktningarna kunnat samsas på skolan, men så icke! Namnet har skolan hämtat från bygdens store och berömde son, men denne son ägnar man enbart musealt intresse! Är det rentav så att svenskt kultur- och kyrkoliv regeras av Jantelagen?

Boken om Grundtvig och Geijer är ett resultat av ett symposium på Högskolan i Karlstad 1966 (Högskola i Sverige är ett ännu inte färdigutvecklat universitet). Björn Skogar på Högskolan i Karlstad och Kim Arne Pedersen på Grundtvig-Centret i Århus var de drivande krafterna bakom symposiet.

Rolf Karlbom ger ett historiskt-biografiskt porträtt av Geijer, sätter in honom i sin miljö och släkt, skildrar hans utveckling och hans verksamhet som professor i historia vid Uppsala universitet.

Göran B. Nilsson skriver om Geijer som tonsättare men sätter också in den musikaliska verksamheten i ett samhällsperspektiv. När någon t.ex. klandrar Geijers musik för att vara trivial, lättfattlig och lättförståelig kan denna kritik bemötas med argumentet att det är just det som är avsikten. I musiken finns Geijers samhällsprogram men också ouppklarad kärlek. Nilsson redogör för en kärlekshistoria i Uppsala som visar att även en stor gigant har svagheter som andra människor.

Lennart Hedvall presenterar Geijers sånger som han delar upp i fyra kategorier: naturskildringar och stämningsstycken, genrebilder i tidens stil, humoristiska reflexioner samt personliga tankedikter med allvarlig och ofta religiös grundton. Typiskt nog - för Sverige - nämner Hedvall inte de båda psalmer genom vilka arvet från Geijer alltjämt är levande, passionspsalmen $D u$ bar ditt kors, o Jesu mild och påskpsalmen Du segern oss förkunnar (Svenska Psalmboken nr. 140 respektive 150) - psalmer som är älskade och som ofta sjunges under fastan och påsk.

Kim A. Pedersen har två uppsatser i boken. I den första för han samman Grundtvig och Geijer och pekar på både likheter och skillnader. Även om skillnaderna överväger är det intressant att se hur de båda giganterna också kan förenas. Pedersen nämner också det som brukar kallas för Grundtvigs mageløse opdagelse och som blev avgörande för bibel- och kyrkosynen. Kyrkan finns före Bibeln, och det levande ordet i dop och nattvard förmedlar mötet mellan den levande, nutidige Kristus och människorna. Kristendomens grund är inte Bibeln utan kyrkan.

Gemensamt för Geijer och Grundtvig är, framhåller Pedersen, deras intresse och engagemang för det nordiska. En intressant iakttagelse har Pedersen gjort: Grundtvig lyssnade till läsning av Geijers historieskrivning samma dag han dog.

Pedersen ger också, i sin andra uppsats, en utmärkt redogörelse för Grundtvigs syn på kristendom och folkliv. Såväl Grundtvigs glada kristendom, som värderar människoliv och kulturliv positivt, och folkeligheden skildras. Folklighet och kristendom skall enligt Grundtvig vara åtskilda men växelverka. Folkligheten är en förutsättning för att en människa skall kunna ta emot det kristna evangeliet. Folkligheten hör samman med skapelsetanken. Som en him- 
melsk gäst kommer kristendomen för att tjäna folkligheten. Skapelsen och kyrkan är också grundstenarna i Grundtvigs teologi; den kollektiva kyrkan och antropologin där det folkliga kommer till uttryck. Kristen kan man enligt Grundtvig endast vara i kyrkan, i församlingen, medan det enligt Geijer är möjligt att vara kristen på egen hand.

Grundtvigs syn på folklighet och kultur gör att han kan se spår av skapelsen också i det hedniska. Kristendomen måste anknyta till det folkliga och därför är det angeläget att den förhåller sig positivt till ett folks kultur. Det är människolivet i dess folkliga gestalt som skall frälsas.

Jens H. Schjørring har en intressant genomgång av en av Grundtvigs dikter, De to Disciplers Gang til Emaus. Schjørring visar hur Grundtvig i sin utläggning av budskapet i Emmausberättelsen målar upp en scen som de danska läsarna eller lyssnarna genast känner igen: landskapet är Danmark och vandrarna i texten de själva. Hela tiden finns en växling mellan den ursprungliga ramen för berättelsen och den livsvärld i vilken vi lever i dag. Personerna som skildras utrustas med allmänmänskliga drag. Gudstjänstens tilltalsord finns där också: »det är dig det handlar om, det är dig det gäller«. Vidare skildras $\mathrm{i}$ dikten nattvardens sakrament och kyrkan som historisk företeelse.

K.E. Bugge skriver om den grundtvigska berättartraditionen och visar vilken betydelse berättelsen intagit i både skolan och kyrkan i Danmark. I folkhögskolan kom berättelsen från början att inta en stor plats, men även i friskolan och senare också i folkskolan skulle berättelsen få en viktig pedagogisk betydelse. Berättelsen är emellertid hotad i den danska kristendomsundervisningen. Så sent som 1989 tillmättes ur Bibeln en avgörande betydelse för kristendomskunskap i historia och nutid. Men 1993 kom en ny folkskolelag, där en existentiell pedagogik betonas medan berättelsen - den bibliska berättelsen - får en underordnad betydelse. Bugge är med rätta oroad över att berättelsen nedvärderas, eftersom detta påverkar både undervisning och kulturliv negativt.

Harry Aronson tar upp temat folklighet och personlighet i Danmark och Sverige. Dessa båda begrepp, folklighet och personlighet, är centrala $\mathrm{i}$ både Danmark och Sverige.

Grundtvigs folkhögskoletanke blev känd i Sverige, och snart började en rad folkhögskolor växa fram. Dessa skulle emellertid inte komma att vila på de idéer som var bärande för Grundtvig utan på tankar som var aktuella i Sverige och som dominerade den svenska debatten. Folkhögskolan blev därmed inte den bro mellan danskt och svenskt kulturliv som den skulle kunnat bli, om den i Sverige hade bevarat den öppenhet som från början präglade den danska folkhögskolan. Ett positivistiskt drag kom att prägla pedagogiken i Sverige, och den filosofi som utvecklades av Uppsalafilosofen Christopher Jakob Boström, en teistisk filosofi, skulle bli den svenska folkhögskolans ideologiska bas.

Vad finns det då som är gemensamt för Danmark och Sverige? Grundtvig och Geijer. Ja. Men på ett överraskande och intressant sätt för Aronson in en 
tredje person som själva brobyggaren, Per Henrik Ling, »den svenska gymnastikens fader «. Hos Ling finner Aronson en skapelseteologi som tar vara på tanken att människokroppen är Guds goda skapelse. Just på gymnastikens område har skett möten mellan svenska akademiker och danska folkhögskoleelever. Människan som kropp, själ och ande betonas av Ling.

Liksom Pedersen betonar Aronson att Grundtvig kunde ge hedendomen ett mänskligt ansikte och se gudsbilden i människan även utanför det kristliga sammanhanget.

Aronson citerar Ernst Trier som menar att gymnastiken blir ett medel som kan hjälpa fram gudsbilden i människan, så att människan skiljer sig från djuret. Lings uttryck en gudsbilden värdig människotyp blir slutvinjetten $\mathrm{i}$ Aronsons uppsats. Grundtvig och Geijer, och mellan dem P.H. Ling och gymnastiken som en bro - en andefylld gymnastik som hjälper människan att se sig som en Guds skapelse, knuten till en dimension utanför henne själv.

Boken är väl värd att läsa, och den ger antydningar som hjälper den uppmärksamme läsaren att förstå de kulturella skillnaderna mellan Danmark och Sverige, men också att se eller ana en bro som förenar de bägge ländernas kultur och kristendomstolkning. Om något negativt skall sägas om boken så är det att man har slarvat med korrekturläsningen och att det bort finnas en presentation av författarna. Kanske kunde också Grundtvigs och Geijers födelse- och dödsår angetts redan i bokens början. Men budskapet går fram, och det är det viktigaste.

\section{Kvartetten Kingo, Brorson, Grundtvig og Ingemann}

\section{Af Hans Boas}

Et kor af stemmer. Tematiske lasninger af salmebogen. Redigeret af Kirsten M. Andersen. Forlaget Anis. København 1997. 266 sider. 249 kr.

"Salmebogen er, kunne man sige, et kor af stemmer, der slår bro mellem de bibelske skrifter og søndagens aktuelle menighed.« Sådan indleder Kirsten M. Andersen disse tematiske læsninger af Den danske Salmebog. I ni artikler belyser hver af forfatterne udvalgte salmer i en beskrivelse af det frelseshistoriske perspektiv, i analyser af hjertet som metafor, i tolkninger af døgnets vekslen mellem dag og nat, af landskabers og årstiders skiften. Mange af salmerne sammenkæder de forskellige motiver, hvorfor de samme salmer da også indgår i flere af artiklerne. Det har været hensigten at lade salmebogen fremstå som »et kor af stemmer«, men i næsten alle artiklerne er det de fire 